\title{
IMPROVING DESCRIPTIVE WRITING SKILL THROUGH CONTEXTUAL APPROACH IN 4 GRADERS OF ELEMENTARY SCHOOL OF 1 PADAAN
}

\author{
Ika Nurwulandari ${ }^{1}$, Anna Mariyani ${ }^{2}$ \\ ${ }^{1}$ STKIP Muhammadiyah Blora \\ ${ }^{2}$ STKIP Muhammadiyah Blora \\ 1ikanurwulandari123@gmail.com, 2annamariyani@gmail.com
}

\begin{abstract}
The success of the teaching and learning process is largely determined by students' ability to write. However, most teachers still apply inappropriate teaching methods, so this is important to find new innovations in teaching. One of them is through contextual approach. This study aims to find out whether the contextual approach can improve the $4^{\text {th }}$ graders' descriptive writing skills or not. This is a classroom action research in the form of collaboration between researchers and class teachers. the data source used was information data from the people as participants. They are $4^{\text {th }}$ graders teacher, students' daily test scores, observations of the learning process using a contextual approach, and other information about the school and its history. To test the validity of the data the writer uses triangulation. The analysis technique used is data reduction, data presentation, and drawing conclusions. The result of the study shows that the contextual approach can improve $4^{\text {th }}$ grader's descriptive writing skills of SDN 01 Padaan, Japah, Blora in the academic year of 2019/2020.
\end{abstract}

Keywords: descriptive writing, contextual approach

\begin{abstract}
Abstrak
Keberhasilan proses belajar mengajar sangat ditentukan oleh kemampuan siswa dalam menulis. Namun banyak guru yang masih menerapkan metode pengajaran yang belum tepat, sehingga penting untuk menemukan inovasi baru. Salah satunya melalui pendekatan kontekstual. Tujuan penelitian ini adalah untuk mengetahui apakah pendekatan kontekstual dapat meningkatkan keterampilan siswa kelas IV dalam menulis deskripsi. Penelitian ini berbentuk classroom action research / Penelitian Tindakan Kelas. Penelitian ini berupa kolaborasi atau kerjasama antara peneliti dengan guru kelas. sumber data yang digunakan adalah informasi data dari narasumber yaitu guru kelas IV, arsip nilai ulangan harian siswa, hasil pengamatan proses pembelajaran dengan menggunakan pendekatan kontekstual, dan informasi lain tentang sekolah dan sejarahnya. Untuk menguji validitas data penulis menggunakan triangulasi. Teknik analisis yang digunakan adalah reduksi data, presentasi data, dan penarikan kesimpulan. Berdasarkan hasil penelitian yang sudah dilakukan dapat ditarik kesimpulan bahwa pendekatan kontektual dapat meningkatkan keterampilan menulis deskripsi pada siswa kelas IV SDN 01 Padaan, Japah, Blora tahun ajaran 2019/2020.
\end{abstract}

Kata Kunci: menulis deskripsi, pendekatan kontekstual

\section{INTRODUCTION}

In modern society, there are two types of communication, namely direct communication and indirect communication. Talking and listening activities are direct communication while writing and reading activities are indirect communication. Listening and reading are passive mastery, while speaking and writing are active mastery. The success of teaching and learning in schools is largely determined by their ability to write. Therefore, learning to write has a very important position in education and teaching. Writing is down or depicting graphic symbols 
that describe a language understood by someone so that other people can read the symbols of the graph if they understand the language and graphic images (HG Tarigan, 2008: 22). In writing, it can be in the form of narration, description, exposition, and argumentation.

Writing skills are one of the highest levels of language skills. Writing is a process of pouring ideas in the form of exposure to written language in the form of a series of language symbols (Baradja, 1975: 42). Zainurrahman (2011: 68) found that "Language skills are divided into two types, namely skills that can only be obtained through exercises and mastery of certain concepts. This is in line with what was stated by Prita (2017: 186) that writing ability is one of the cognitive elements that emphasize memory. The outline is that writing skills are very important in the writing process because these skills contain expertise in structure, group of words, traits or the nature of the word, and the formulation of the topic. Finally, language skills contain the sequence or arrangement of writing, vocabulary, and use of grammar. In other words, writing skills are not only language skills but also central in the writing process that requires expertise or mastery of the components needed to write. Tarigan (1987: 21) expresses the purpose of writing is to tell or teach, convince or urge, entertain or please, and express fiery feelings and emotions. Billow in Pateda (1987) mentions the types of writing as follows: 1) Reports, which are usually writings that contain facts that have been collected in the field. 2) Scales, i.e. writing the contents of the book related to the ideas put forward by the writer, the things that are approved and those that are rejected. 3) Advertising, namely writing in the form of promotional offers. 4) Articles, i.e. scientific papers that discuss actual problems. 5) letter.

The description is the description of a situation/condition so that the reader seems to see, hear or feel it. Form of expression that describes the sensing, the writer's feelings about various kinds of things that are in the arrangement of space, for example, beautiful scenery, melodious song (The Liang Gie, 1992: 18).

Descriptions give a mental image of something that is experienced, such as scenes, people or sensations. The main function of the descriptive essay is to make the reader see the goods or objects, or absorb the distinctive qualities of the items. The description makes us see, that is, to make a visualization of the object, or in other words, the description focuses on the appearance of the goods. In the description we see objects arable in a living and concrete way, we see objects unanimously.

Descriptive paragraph is the description of a situation with sentences, giving a lively impression. Portrayal or painting must be presented as long as possible, so that what is described is living in the minds of readers. 
The description emphasizes the expression through a series of words. Although to make a good description, the writer must first identify, but the understanding of the description only involves the expression through words. By recognizing the characteristics of the arable object, the writer can verbally describe the object that he wants to introduce to the reader. Then it can be concluded that writing a description is describing an object so that the reader seems to see, hear, and feel the things written by the writer.

Meanwhile, according to Aditya Permana (2019: 5), the purpose of writing is that the writer wants to convey a message, message or just provide information about something. Similarly, what was revealed by Azilatul Jannah (2019: 68) states that writing a description aims to make the reader aware of what life the writer absorbs through the senses, stimulating the reader's feelings about what they describe, presenting the quality of direct experience.

According to Hairuddin et al (Dikti Depdiknas, 2007: 2.3), the word pendekatan is interpreted as an approach. In teaching, this word is better interpreted as a way of beginning something. So, if translated, the approach is a way to start something. While broad understanding, the approach is a set of assumptions that are axiomatic about the nature of language, language teaching, and language learning that is used as a foundation in designing, doing, and assessing language teaching and learning process.

Bettye P. Smith in her results of the study stated that contextual teaching and learning is defined as a conception of teaching and learning that helps teachers relate subject matter content to real world situations (United States Department of Education Office of Vocational and Adult Education, 2001). Berns and Erickson (2001) further explain the contextual teaching and learning as an innovative instructional process that helps students connect the content they are learning to the life context in which content could be used. Problem-solving, self-regulated learning, teaching anchored in students' diverse life-contexts, learning from each other and together, authentic assessment, and the use of a variety of contexts such as home, community, and work sites, have been identified as practices of contextual teaching and learning (Sears \& Hersh, 1998). That is why the writer would like to improve students' descriptive writing skills through contextual approach in 4 graders of an elementary school of 1 Padaan.

\section{METHOD}

The research method used in this study is Classroom Action Research. Data collection techniques in Classroom Action Research (CAR) are as follows: (1) Observation; (2) Interview; (3) Distribution of questionnaires; (4) tests; and (5) Documentation. According to 
Suharsimi Arikunto (2008: 129), research required the existence of data validity, the intention is that all data collected should reflect what is actually measured or examined. In this research, to test the validity of the data triangulation and triangulation methods are used. As for what is meant by these two things are:

1. Triangulation of data is the data or information obtained is always compared and tested with other data and information, both in terms of coherent the same source or different sources.

2. The triangulation of methods is a researcher by collecting similar data using different data collection methods. Researchers can use the data collection method in the form of observation and then do in-depth interviews from the same informant and the results are tested by collecting similar data using documentation techniques on the perpetrators of activities. From the data obtained from those obtained through several different data collection techniques, the results are compared and conclusions can be drawn that have stronger validity.

The research plan refers to the research design conducted by Kurt Lewin using the spiral model (Jean Mc Niff, 1988: 22). Levin explained the implementation of the study as a spiral step, each step having 4 parts: Planning, acting, observing, reflecting. In chart form, the procedure can be explained as follows:

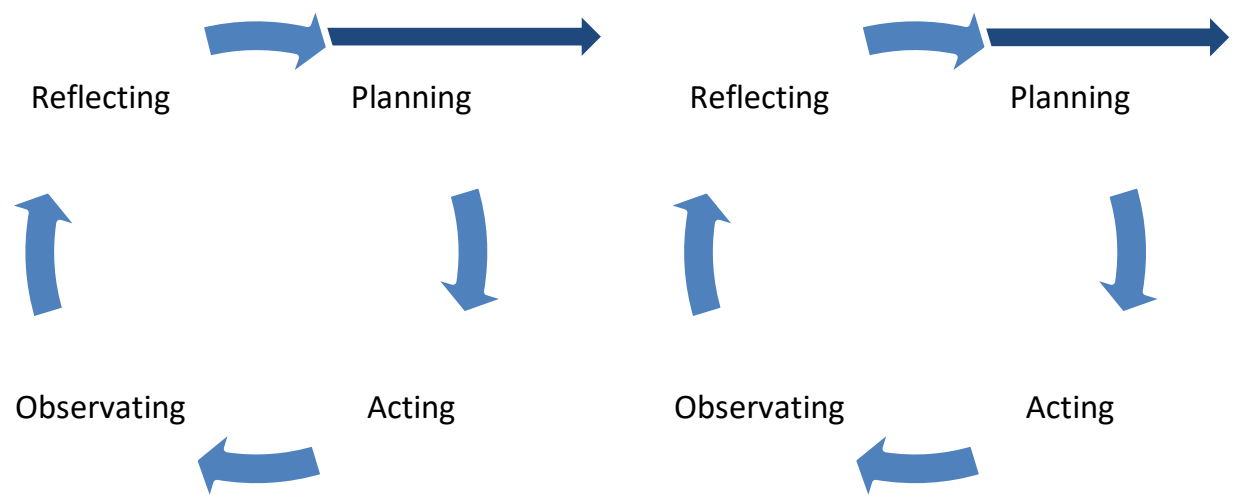

Figure 1. Kurt Lewin spiral model

\section{RESULTS AND DISCUSSION}

\section{Results}

Before carrying out an action or research process, the writer first carried out a preliminary survey activity that aims to know the real conditions. Based on the survey results, the researcher found several learning difficulties experienced by the majority of $4^{\text {th }}$ graders in 
Journal of Elementary Education

Volume 4, Number 1, February 2020
P-ISSN: 2580-9326

E-ISSN: 2580-7714

Indonesian language learning, especially in writing learning activities. The initial condition with the method given by the teacher is indicated by the presence of 13 students or around $44.8 \%$ of students whose grades cannot meet the Minimum Mastery Criteria (KKM) of 65. To anticipate this, the writer conducted a study in $4^{\text {th }}$ graders through the CTL approach (Contextual Teaching and Learning) which can improve writing skills, especially writing descriptions.

\section{Discussion}

The first cycle was carried out twice. Each meeting consists of two hours $(2 \times 35$ minutes). Cycle I carried out for one week.

Value data or evaluation results write a description through the contextual approach of $4^{\text {th }}$ graders of SDN Karanggedang 03 in cycle I can be seen in appendix 7 . The following values data are presented in the form of frequency tables and grading charts.

Table 1. The Data of Description Writing Skills Score Cycle I

\begin{tabular}{cccc}
\hline No. & Score & Frequence & Percentage (\%) \\
\hline 1 & $60-64$ & 4 & 13,8 \\
2 & $65-69$ & 12 & 41,4 \\
3 & $70-74$ & 10 & 34,5 \\
4 & $75-79$ & 2 & 6,9 \\
5 & $80-84$ & 1 & 3,4 \\
6 & $85-89$ & 0 & 0 \\
\hline \multicolumn{4}{c}{ Total } \\
\multicolumn{5}{c}{ Average Score : $\frac{2063}{29}=71,14$} \\
& Level of Completeness : $\frac{25}{29} \times 100 \%=86,2 \%$ \\
\hline
\end{tabular}

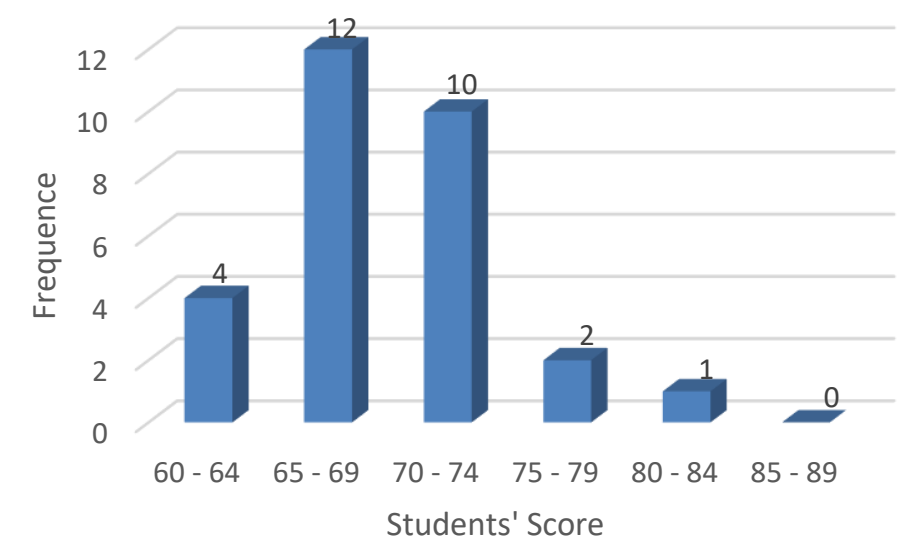

Figure 2. Descriptive Writing Score in Cycle I 
Based on observations, the results of writing descriptions of students can be concluded that students in their group activities are still happy to protest and complain to replace group members. In addition, students are less able to work together with group members. As an improvement in the next cycle, the group formed is the student's own choice, the teacher prepares himself more so that the appearance and delivery of the material in learning can be maximized, so students will more easily accept the material and feel enthusiastic in following the learning, the teacher always provides guidance to all groups, and so that the results obtained are more optimal, the teacher is more creative in creating a learning atmosphere that is fun, active, and fosters student motivation in participating in learning, students are not right in the use of capital letters and punctuation. Learning to write descriptions in cycle II places more emphasis on the use of capital letters and proper punctuation in sentences.

In the second cycle, the results achieved are much better. Rests from the reflection in the first cycle the second cycle is carried out. From the second cycle of action the following results are obtained:

Table 2. Data of Writing Skill Score Cycle II

\begin{tabular}{cccc}
\hline No. & Score & Frequence & Percentage (\%) \\
\hline 1 & $60-64$ & 2 & 6,9 \\
2 & $65-69$ & 7 & 24,1 \\
3 & $70-74$ & 12 & 41,4 \\
4 & $75-79$ & 3 & 10,3 \\
5 & $80-84$ & 4 & 13,8 \\
6 & $85-89$ & 1 & 2,2 \\
\hline \multicolumn{4}{c}{ Average Score: $\frac{2097}{29}=72,31$} \\
\\
& Total & 100,0 \\
\end{tabular}

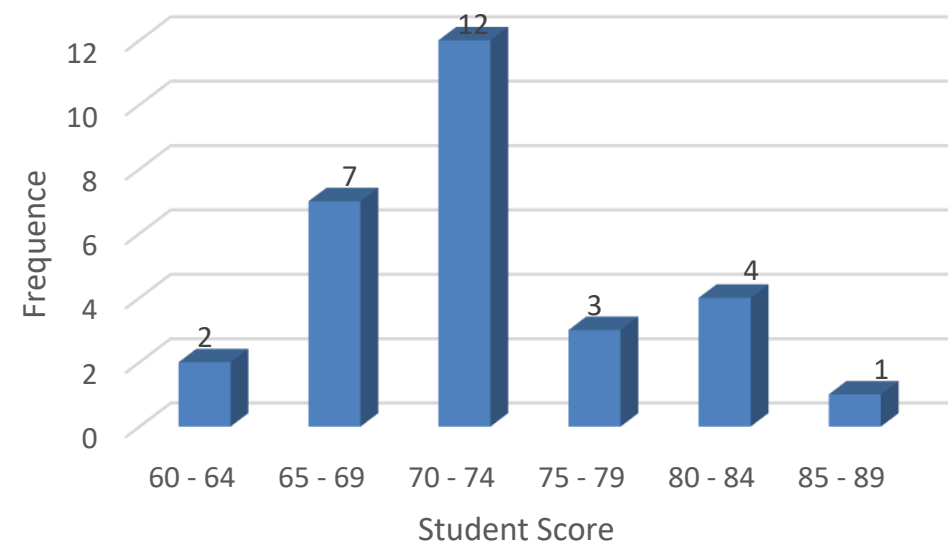

Figure 3. Descriptive Writing Score in Cycle II 
Thus, when compared with the average value in the first cycle, an average increase of 1.17 occurs. The assessment results showed an increase, namely (1) the contents of the essay became better, (2) the composition of the essay became better, (3) the relationship between paragraphs was better, and (4) the use of spelling as well as punctuation and vocabulary were better.

\section{CONCLUSION}

Based on the results of classroom action research that has been carried out in two cycles in an effort to improve writing skills description through a contextual approach to fourth-grade students of the Elementary School of Negeri 1 Japah Blora in the academic year 20019/2020, conclusions can be drawn as follows:

The application of contextual approaches can improve learning in writing a description of grade IV students. This is indicated by the percentage of discipline, readiness to accept learning, activeness, and the ability to conduct student discussions in learning to write descriptions that have increased in each cycle. In the first cycle, the percentage of student discipline was $50 \%$ while in the second cycle increased to $100 \%$, in the first cycle the percentage of students' readiness received $75 \%$ learning while in the second cycle increased by $100 \%$.

Starting from the description above, it can be concluded that the formulated hypothesis has been proven to be true. Thus, learning to write through a contextual approach can improve writing skills in the description in $4^{\text {th }}$ graders of SDN Karanggedang 03 Sidareja Subdistrict Cilacap Regency in the academic year of 2009/2010 school year.

\section{ACKNOWLEDGMENTS}

The writer would like to thank all teachers and students of SDN 1 Padaan as participants of the study. Massive thanks also dedicated to STKIP Muhammadiyah Blora as the writer's workplace that has given permission to carry out the study.

\section{REFERENCES}

Hairuddin dkk. (2007). Pembelajaran Bahasa Indonesia. Jakarta: Dikti Depdiknas.

Jannah, Azaliyatul. (2018). "Pengaruh Pembelajaran TTW Untuk Menulis Deskriptif Dalam Mata Pelajaran Bahasa Indonesia." Universitas Muhammadiyah Sidoarjo.

Johnson, B. Elaine. (2006). Contextual Teaching and Learning. Diterjemahkan oleh Ibnu Setiawan. Bandung: MLC. 
McNiff, Jean. (1988). Action Research-Principles and Practice. Great Britain: Mackays of Chatham PLC.

Permana, Aditya, et al. (2019). "Implementasi Pemanfaatan Latihan Terbimbing dan Pembelajaran Menulis Naskah Drama Berbasis Ekologi Das Citarum." Abdimas Siliwangi 2.2: 103-112.

Santosa, Prita Pantau Putri. ((2017). "Hubungan Antara Penguasaan Tata Bahasa dengan Keterampilan Menulis Narasi Bahasa Inggris Siswa Kelas XI SMK Negeri 2 Depok." Deiksis 9.02: 182-193.

Sears, David O, dkk. (1985). Social Psychology Fifth Edition (Alih Bahasa : Andryanto). Jakarta : Erlangga.

Smith, Bettye P. (2006). Contextual Teaching and Learning Practices in The Family and Consumer Sciences Curriculum. Georgia: University of Georgia. Journal of Family and Consumer Sciences Education. Vol. 24, No. 1, Spring/Summer.

Sugandi, Asep Ikin, and Martin Bernard. (2018). "Penerapan Pendekatan Kontekstual Terhadap Kemampuan Pemahaman Dan Komunikasi Matematis Siswa Smp." Jurnal Analisa 4.1: 16-23.

Suharsimi Arikunto. (2008). Penelitian Tindakan Kelas. Jakarta: Bumi Aksara.

Tarigan, Guntur Hendry. (2008). Metodologi Pengajaran Bahasa. Bandung: Angkasa.

The Liang Gie. (1992). Pengantar Dunia Karang Mengarang. Yogyakarta: Liberty.

Zainurrahman. (2011). Menulis Dari Teori Hingga Praktik (Penawar Racun Plagiarisme). Bandung: Penerbit Alfabeta. 